WwW.iibpas.com

\title{
SHATAVARI (ASPARAGUS RACEMOSUS) MEDICINAL PLANT BILOGICAL ACTIVITY OVERVIEW
}

\begin{abstract}
BONGIRWAR AA*, BONGIRWAR GA AND TONGE V
*Corresponding Author: Dr. Amol Ashok Bongirwar: E Mail: pharmarxpro@gmail.com

Received 13 ${ }^{\text {th }}$ Jan. 2020; Revised 12 ${ }^{\text {th }}$ Feb. 2021; Accepted 11 ${ }^{\text {th }}$ March 2021; Available online $1^{\text {st }}$ Nov. 2021 https://doi.org/10.31032/IJBPAS/2021/10.11.5701

ABSTRACT

Asparagus racemosus, a climbing Ayurvedic plant, is known for its numerous activities such as hyperlipidemia, hypertension, angina, dysmenorrhea, anxiety disorders, benign prostatic hyperplasia (BPH), leucorrhoea and urinary tract infections. This plant possesses a wide range of secondary metabolites inclusive of steroids, alkaloids, dihydrophenanthrene derivatives, flavonoids, furan derivatives and essential oils. Information from the literature suggests that, the major constituents of $A$. racemosus are steroidal saponins which are mainly responsible for different biological activities of $A$. racemosus. The review summarizes the information concerning the cultivation, morphology, phytochemistry, biological activities, safety profile, marketing status and conservation techniques of $A$. racemosus.
\end{abstract}

Keywords: Asparagus racemosus, Shatavarins, Racemosides, Formulations \section{INTRODUCTION}

The genus Asparagus consisted of about 300 species around the world, out of which 22 species are recorded in India. $A$. racemosus is widely distributed across the globe and its distribution ranges from tropical Africa, Java, Australia, Sri Lanka, Southern parts of China and India, but it is mainly cultivated in India [1].

Classification:

Kingdom : Plantae

Order : : Asparagales

$\begin{array}{ll}\text { Family } & \text { : Asparagaceae } \\ \text { Sub family } & \text { : Asparagoideae } \\ \text { Genus } & \text { : Asparagus } \\ \text { Species } & \text { : Asparagus racemosus L } \\ \text { Vernacular } & \text { names [2] } \\ \text { Sanskrit } & \text { : Satavari } \\ \text { Hindi } & \text { : Satavari, Shatawar or Satmuli } \\ \text { Bengali } & \text { : Shatamuli } \\ \text { Marathi } & : \text { Shatavari or Shatmuli } \\ \text { Gujarati } & \text { : Satawari } \\ \text { Telegu } & \text { : Toala-gaddalu or Pilli-gaddalu } \\ \text { Tamil } & \text { : Shimaishadavari or Inli-chedi }\end{array}$


Malayalam : Chatavali

Kannada : Majjigegadde or Aheruballi

Madhya Pradesh: Narbodh or atmooli

Kumaon : Kairuwa

Rajasthan : Norkanto or Satawar

A. racemosus is an important medicinal plant which is regarded as a 'rasayana' which means plant drugs promoting general well-being by increasing cellular vitality and resistance [3].

Use of $A$. racemosus is mentioned in the ancient literature of Ayurveda (Charaka samhita) [4]. Traditionally, A. racemosus is indicated in epilepsy, vata disorders [5], brain tonic, helps in regulating cardiac disorders and hypertension [6].

It is extensively used in male genital dysfunctions, oligospermia, spermatogenic irregularities and other male disorders such as painfull micturition $[7,8]$. It is also explored in Ayurvedic formulations for digestive discomfort, indigestion, amoebiasis, piles and debility $[9,10]$. In females, prescribed by the doctors in habitual abortions, weakness of the uterus, excessive bleeding during menstruation [11]. Recent reports and experiments disclosed Shatavari as antidiarrhetic [12], antispasmodic, aphrodisiac [9], antidysenteric, demulcent, diuretic [13], galactagogue, nutritive, mucilaginous, refrigerant, stomachic properties and works as a tonic for human beings [14]. It is also known to reinforce the immune system and protect vital organs like heart [15], brain [16] and other organs of the body. This review is a discussion about the cultivation, morphology, phytochemistry, biological activities, safety profile and conservation techniques for this plant.

\section{Cultivation and Morphology: In}

Thailand, traditionally the decorticated roots of the plant have been used as a remedy for diseases of spleen, liver and other internal organs, including preventing miscarriage [17]. In India, conventionally the roots have been utilzed during internal pain, tumors, fever and as a tonic [18]. $A$. racemosus (Shatavari) is a climbing plant consisting of tuberous roots [5]. According to Indian pharmacopoeia, $A$. racemosus contains not less than 0.1 per cent of Shatavarin IV, ascalculated on the dried weight basis [14]. The taste is initially starchy and then slightly bitter followed by a sweet taste. $A$. racemosus has small pinneedle like phylloclades (photosynthetic branches) which are uniform and shiny green in appearance.

The roots, $5-15 \mathrm{~cm}$ in length and $2 \mathrm{~cm}$ in thickness, are marketed in the form of pieces. These are silvery white or ash-color externally and white internally. Roots are more or less smooth when fresh, and start to develop longitudinal wrinkles upon drying [10]. Microscopically the inner parenchymatous zone of cortex is composed of 18-24 layers in the upper portion and 42-47 layers in the middle 
tuberous portion of the roots. Cells are thinwalled and composed of cellulosic fibres; with circular to oral outlines and distinct inter cellular spaces. In some roots 3-4 layers of cortex immediately adjacent to the endodermis are modified into a sheath of stone cells round the endodermis.

The number of vascular bundles ranges from 30-35 in the upper levels and 35-45 in the middle tuberous portions of the roots [16]. The roots upon grinding are light brown in colour with a coarse texture (Figure 1). The plant prefers light (sandy), medium (loamy) and heavy (clay) soil.
Black, well drained and fertile soil are highly favourable for $A$. racemosus cultivation [4] and can also be cultivated in loose and medium black soil. Crops mainly need tropical, hot climatic conditions and require minimum irrigation with the avoidance of over-watering. Raised beds which are about $3 \mathrm{~m}$ are harvested in the month of May or June. The time of transplanting is in the month of July-August. It produces minute flowers in the month of July which are white and unisexual in nature [19].

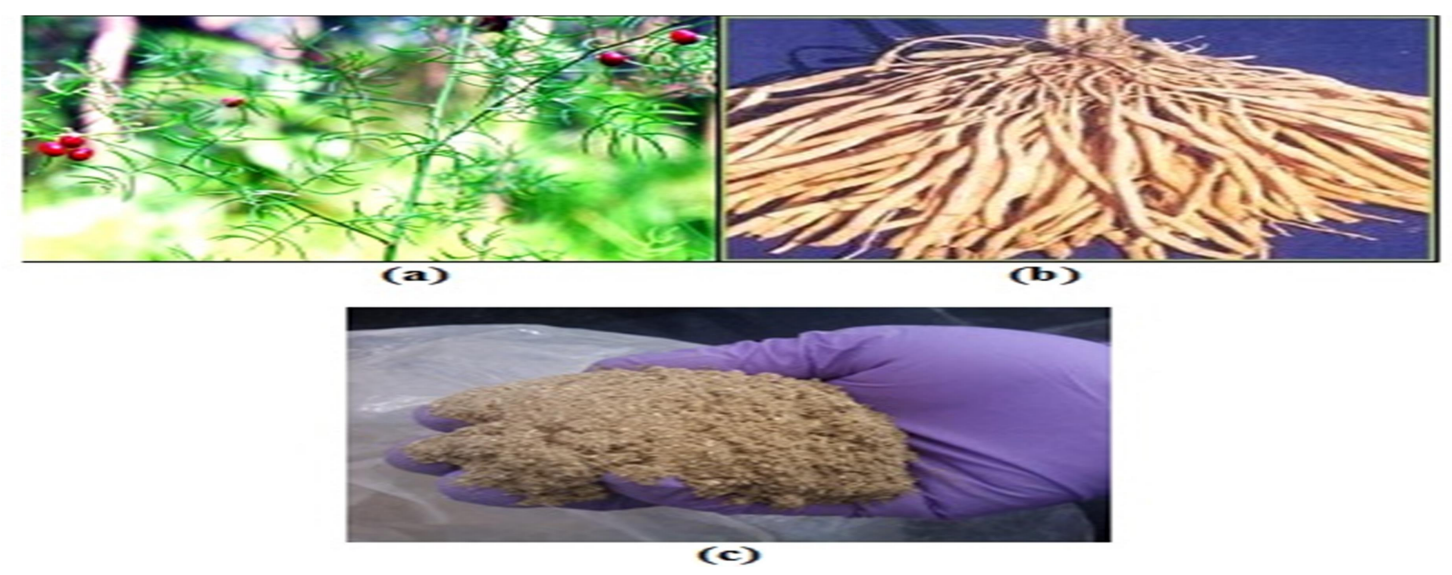

Figure 1: Photographs of Asparagus racemosus showing (A) shoot, leaves and berries [20] (B) Tuberous Roots [12] (C) Powdered Roots

In September, it begins to bear fruits which are globular or obscurely 3 lobed, pulpy berries which are purplish black when they are ripening, seeds are hard and brittle [14]. Weeding operations are to be timely carried out. Generally the crops are not affected with pest and diseases. The first harvesting is done after 1.5-2 years of transplanting, which is continued for 10-15 years. Male and female plants are grown if seed is required [4].

Analytical techniques: Analysis of Shatavarin $\mathrm{V}$ from the root extract was performed with RP-HPLC method [22]. In another study analysis of sarsapogenin in $A$. racemosus extract under isocratic conditionsby RP-HPLC [23] has been reported. Shatavarin I and IV have been 
analyzed using HPLC with Evaporative Light Scattering Detector (ELSD) using a solvent system of $57.3 \%$ ethyl acetate in methanol [24]. Presence of fructooligosaccharides (FOS) was reported by enzymatic, size exclusion, gas chromatography with flame ionization detector (GC-FID), high pressure anion exchange chromatography (HPAEC) and thin layer chromatography methods [25].

Phytochemicals: $A$. racemosus consists of a diverse range of molecules in which major constituent is steroidal saponins along with alkaloids, flavonoids, dihydrophenanthrene derivatives, furan derivatives (Table 1) and volatile constituents (Figure 2-3). Twenty nine steroidal saponins (1-27) were reported from $A$. racemosus. An oligospirostanoside (1) named 3-0-[ $\alpha$-L-rhamnopyranosyl-( $1 \rightarrow 2)$ $\alpha$-L-rhamnopyranosyl- $(1 \rightarrow 4)-O-\beta$-Dglucopyranosyl]-25(S)-spirosta-3 $\beta$-oil is obtained from $A$. racemosus which on oral administration potentiated antibody synthesis and enhanced cell-mediated immune response in immune compromised animals [26]. Shatavarin VI (5) and Shatavarin VII (6) were reported which are specific A.racemosus

[28]. $(1 S, 2 R, 3 S, 8 S, 9 S, 10 S, 13 S, 14 S, 16 S, 17 R, 22 R$,

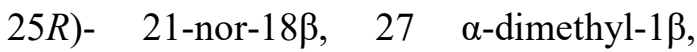
$2 \beta, 3 \beta$-trihydroxy-25-spirost-4-en-19 $\beta$-oic acid (15) which was reported to have immunostimulant property.
Sitosterol (20) [32, 33]; Shatavaroside A (26) and Shatavaroside B (27) [37]; Asparagamine A (28) [38]; polycyclic alkaloid (29) [39] and Racemofuran (31) isolated from $A$. racemosus possess an immuno-modulatory activity [3], antioxytocic property [38], human stomach cancer cells (KATO-III) in cultures with $\mathrm{IC}_{50}=79$. $81 \mu \mathrm{g} / \mathrm{ml}[39]$ and anti-oxidant activity $\mathrm{IC}_{50}$ value of $130 \mu \mathrm{M}[17]$ respectively (Figure 2).

Essential oil constituents: Fifty five essential oil constituents were extracted from aerial parts pertain to a diverse range of chemical classes such as acids, alcohol, aldehyde, ester, hydrocarbon, ketone, $N$ containing compounds. The major ones being borneol (40), myrtanol (41), pinocarveol (42), 2-ethylhexanol (43) perillaldehyde (44), 4-[1-hydroxyethyl] benzaldehyde (45), hexanal (46), furfural (47), decanoic acid (48), undecanoic acid (49), camphor (50), 6, 10, 14-trimethyl pentadecanone (51), [E]-4-hexadecen-6yne (52). Remaining chemical classes which consisted of ester, $\mathrm{S}$ and $\mathrm{N}$ containing compounds were detected at lower concentration. Only three compounds; borneol (40), myrtenol (41) and paraldehyde (44) occupied $45.09 \%$ of the (Figure 3) whole content [43].

Roots were also reported to contain (4,6dihydryxy-2-O(-2-hydroxy isobutyl) 
benzaldehyde (53) and undecanyl the state Uttranchal, India [45]. Their study cetanoate (54) [31].

indicated that there is much variation in the

Miscellaneous: The variation in the trace element content with the changing content of trace element (Table 2) was also altitudes and the best altitude for the carried out by collecting plantfrom the cultivation is 2250 meters.

different regions, varying in altitudes from

Table 1: Phytochemicals Isolated From Asparagus racemosus

\begin{tabular}{|c|c|c|c|c|}
\hline $\begin{array}{l}\text { S. } \\
\text { No. }\end{array}$ & Name & Category & $\begin{array}{c}\text { Plant } \\
\text { part }\end{array}$ & Reference \\
\hline 1 & 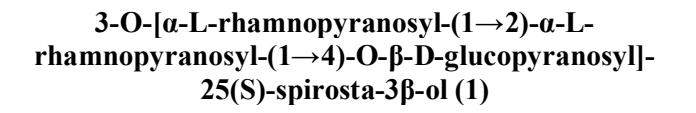 & Steroidal & Roots & 26 \\
\hline 2 & Racemoside A, B, C (2-4) & Steroidal & $\begin{array}{l}\text { Defatted } \\
\text { fruits }\end{array}$ & 27 \\
\hline 3 & Shatavarins (5-12) & Steroidal & Root & 28 \\
\hline 4 & Asparanin A (13) & Steroidal & Roots & 29 \\
\hline 5 & Immunoside (14) & Steroidal & Roots & 29 \\
\hline 6 & 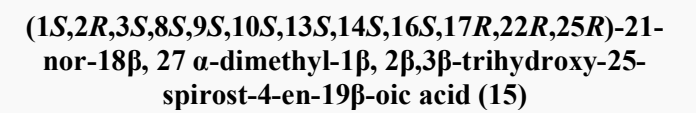 & Steroidal & Roots & 30 \\
\hline 7 & Sarsasapogenin (16) & Steroidal & Roots & 31 \\
\hline 8 & Diosgenin (17) & Steroidal & Roots & 31 \\
\hline 9 & Sitosterol (18) & Steroidal & Roots & $32,33,34$ \\
\hline 10 & Anti-HIV compounds (19-24) & Steroidal & Root & 35 \\
\hline 11 & Filiasparoside C (25) & Steroidal & Root & 36 \\
\hline 12 & Shatavaroside A (26) & Steroidal & Root & 37 \\
\hline 13 & Shatavaroside B (27) & Steroidal & Root & 37 \\
\hline 14 & Asparagamine A (28) & Alkaloid & Root & 38 \\
\hline 15 & Polycyclic alkaloid (29) & Alkaloid & Root & 39 \\
\hline 16 & $\begin{array}{c}\text { Racemosol (9, 10-dihydro-1, 5-dimethoxy-8-methyl-2, } \\
\text { 7-phenanthrene diol) (30) }\end{array}$ & $\begin{array}{l}\text { Dihydrophenanthrene } \\
\text { derivative }\end{array}$ & Root & 40 \\
\hline 17 & Racemofuran (31) & Furan derivatives & Root & 17 \\
\hline 18 & $\begin{array}{c}\text { 8-Methoxy-5,6,4-trihydroxyisoflavone-7-O- } \beta \text {-D- } \\
\text { glucopyranoside (32) }\end{array}$ & Flavonoid & Root & 41 \\
\hline
\end{tabular}


Cyanidine-3-galatoside (33)

20

Kaempferol (34)
Woody portions $[1 \rightarrow 4]$-O- $\alpha$-D-xylopyranoside $(35)$

Quercetin (36)

Rutin (37)

24

Hyperoside (38)

25



22

23

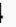

Quercetin-3-glucuronide (39)
Flavonoid

Flavonoid

Flavonoid

Flavonoid

Flavonoid

Flavonoid of tuberous roots

Woody

portions of tuberous roots

31

Leaves $\quad 42$.

Flowers

and fruits

Flowers

and

fruits

Flowers

and

fruits

Leaves
-

2

2

Table 2: Trace Elements from the Asparagus racemosus

\begin{tabular}{cccc} 
S. No. & Metal & Root $(\mathrm{mg} / \mathrm{kg})$ & \multicolumn{1}{c}{ Leaves $(\mathrm{mg} / \mathrm{mg})$} \\
\hline 1 & Zinc & $44.0 \pm 0.2$ to $148.0 \pm 1.2$ & $53.0 \pm 0.2$ to $165.0 \pm 3.2$ \\
2 & Copper & $14.0 \pm 0.1$ to $23.0 \pm 0.3$ & $15.0 \pm 0.6$ to $34.0 \pm 0.5$ \\
\hline 3 & Manganese & $5.0 \pm 1.4$ to $62.0 \pm 2.5$ & $14.0 \pm 0.4$ to $84.0 \pm 0.7$ \\
4 & Iron & $211.0 \pm 0.5$ to $1493.0 \pm 0.2$ & $505.0 \pm 0.2$ to $2040.0 \pm 0.3$ \\
5 & Cobalt & $84.0 \pm 0.3$ to $122.0 \pm 1.5$ & $85.0 \pm 0.3$ to $88.0 \pm 0.2$ \\
6 & Sodium & $199.0 \pm 0.5$ to $490.0 \pm 20$ & $127.0 \pm 0.6$ to $745.0 \pm 0.3$ \\
7 & Potassium & $2652.0 \pm 0.4$ to $13260.0 \pm 3.5$ & $5460.0 \pm 0.2$ to $10842.0 \pm 2.5$ \\
8 & Calcium & $961.0 \pm 0.6$ to $2115.0 \pm 3.2$ & $1346.0 \pm 0.3$ to $6153.0 \pm 1.6$ \\
9 & Lithium & $18.0 \pm 0.2$ to $58.0 \pm 3.8$ & $28.0 \pm 0.6$ to $48.0 \pm 1.6$
\end{tabular}





Figure 2: Structures of steroidal saponins, alkaloids, dihydrophenanthrene, furan derivative, flavonoids from Asparagus racemosus 


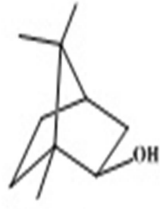

40 Bbracol<smiles>CCCCCC=O</smiles>

46 Hexanal<smiles>CCC1CC2CCC(C)(C2)C1C</smiles>

41 Mlyrteal

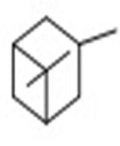

42. Pisscarvel


432-ethyltactasol

4 Perillaldelyde<smiles>CCCCCCCCCCC(=O)O</smiles>

49) Undxanok acid

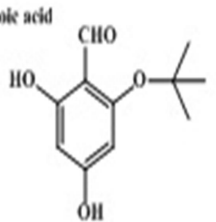

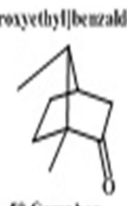

so Camphor<smiles>CCCCC=CCCCCCCCCCCCC(C)=O</smiles>

$52|\mathbf{E}| \cdot-4 \cdot$ beudexen-6-yne

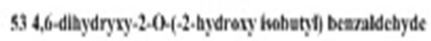
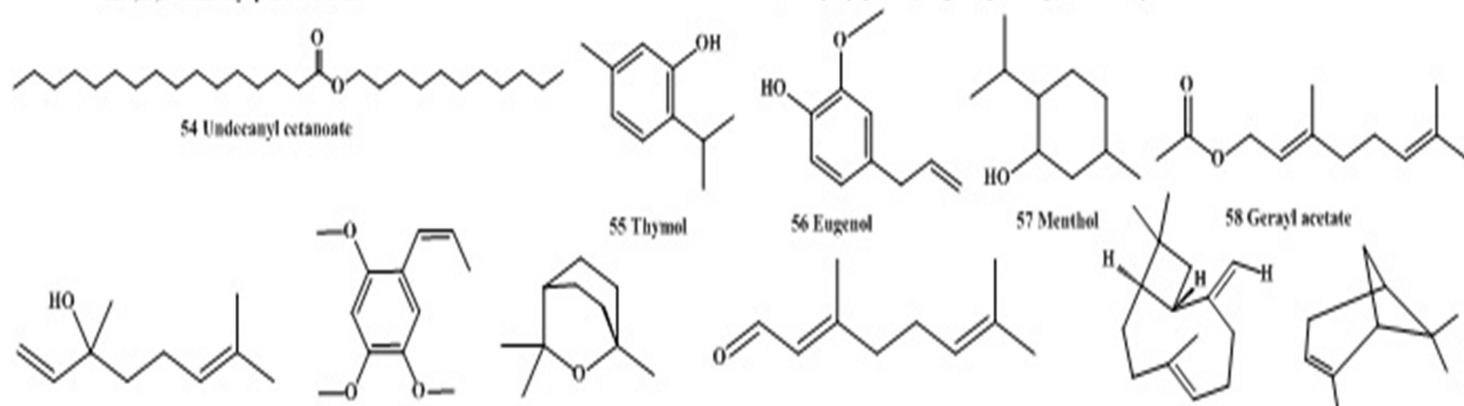

59 Limalool
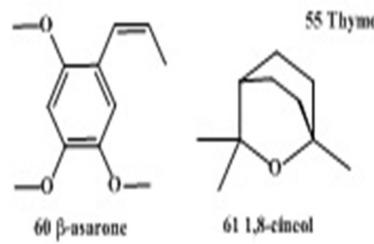

61 1.8-incal
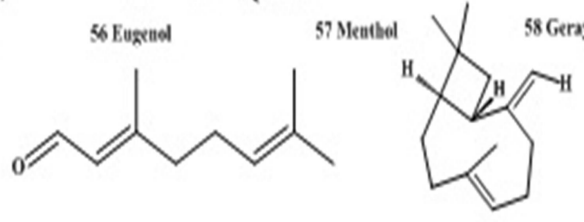

63 B-sanuphistlene
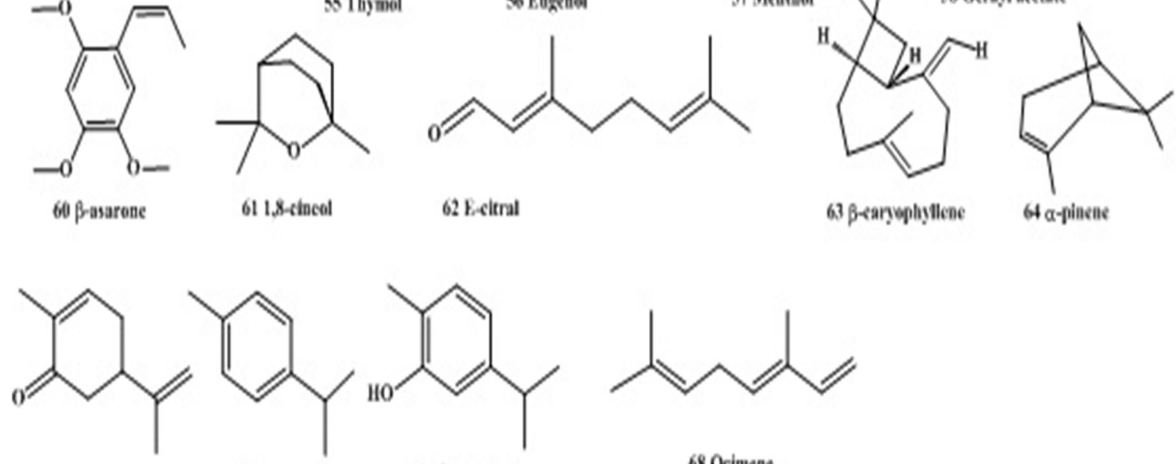

68 Carvone<smiles>Cc1ccc(C(C)C)c(C)c1</smiles>

66 peymene

67 Carvacrol

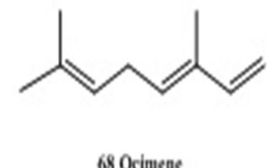

68 Ocimene

Figure 3: Structure of volatile components from asparagus racemosus

Biological activities: The second century physician Galen described Asparagus as

"cleansing and healing". Nutritional studies demonstrated that Asparagus is a lowcalorie source of folate and potassium. In the first century, Pliny wrote, 'Asparagus, of all the plants of the garden, receives the most praiseworthy care'.

The plant is widely used in about 64 Ayurvedic formulations which include traditional formulations such as 'Shatavari
Kalpa', 'Phalaghrita', 'Vishnu taila' [2]. The plant has numerous traditional practices and these traditional practices were verified by the experimental studies.

\section{Antioxidant property: Crude} extract and purified aqueous fraction of A.racemosus have been demonstrated for its antioxidant effect [46]. The activity was tested in rat liver cell mitochondrial membrane damage induced by 
generated free radicals. The lipid peroxidation induced was evaluated by the formation of thiobarbituric acid reactive substances (TBARS) and lipid hydroperoxides (LOOH) $[47,48]$. The extract exhibited antioxidant effect against oxidative damage by providing protection against lipid peroxidation, protein oxidation and depletion in the levels of protein thiols and antioxidant enzyme, superoxide dismutase. The purified aqueous fraction which consisted of polysaccharides was found to be a potent antioxidant as compared to the crude extract. Purified fraction was more effective against lipid peroxidation whereas the antioxidant effect of the crude extract was more effective in inhibiting protein oxidation.

The crude and purified extracts indicated protection against radiation induced loss of protein thiols and inactivation of superoxide dismutase [46]. Racemofuran (31) and asparagamine A (28) from chloroform extract showed antioxidant activity against DPPH [17]. A similar study indicated that an increase in the antioxidant defence owing to the significant increase in the enzymes superoxide dismutase, catalase, and ascorbic acid and significant decrease in lipid peroxidation upon treatment with A.racemosus root extract [49]. Anti-oxidant study was carried out on the basis of scavenging activity of the stable DPPH (1, 1-diphenyl-2picrylhydrazyl) free radical. The antioxidant property observed was due to their redox property of the phenolic compounds present in the ethanolic root extract [50].

2. Diuretic activity: The diuretic property was highlighted in Ayurveda has been validated by a suitable experimental model. Study was carried out using an aqueous extract of the roots utilizing three dose vials $800 \mathrm{mg} / \mathrm{kg}, 1600 \mathrm{mg} / \mathrm{kg}$ and $3200 \mathrm{mg} / \mathrm{kg}$ for its diuretic activity in comparison with standard drug (furosemide) and control (normal saline) rats after performing acute toxicity tests. The extract demonstrated diuretic activity at a $3200 \mathrm{mg} / \mathrm{kg}$ dose without any acute toxicity [51].

\section{Antidepressant}

activity: Antidepressant activity was evaluated in mice using tail suspension test (TST) and forced swim test (FST). The methanolic extract decreased immobility 
periods significantly in TST, FST, which indicated significant antidepressant activity underlining the fact that the efficiency of the extracts was comparable to fluoxetine and imipramine used as reference drugs in the study. Methanolic extract administered to mice significantly decreased brain MAO-A (Monoamine Oxidase A) and MAO-B (Monoamine Oxidase B) activity levels it has been found that the methanolic extract possesses antidepressant activity probably by inhibiting MAO-A and MAO-B; and through interaction with adrenergic, dopaminergic, serotonergic and GABAergic systems (Gamma aminobutyric acid) [52].

Experiments have been performed on rats using the methanolic extract and subjected to forced swim test (FST), learned helplessness test (LH) and it has been found that the extract decreases immobility in the FST and increases avoidance response in $\mathrm{LH}$ indicating antidepressant activity. Behavioural experiments were conducted, extract administered increased the number of head twitches produced by 5-HT (5-hydroxy tryptamine), increased clonidine-induced aggressive behaviour and it was concluded that the methanolic extract has a significant antidepressant activity mediated via serotonergic, noradrenergic systems and precipitation of antioxidant defences [53]. Inhibitory activities of different extracts were determined on the basis of enzyme kinetics of acetyl and butyryl cholinesterases, and monoamine oxidase [54]. Methanolic extract significantly inhibited cholinesterase and MAO activities and act as a non-selective competitive inhibitor as compared hexane and chloroform extracts. It indicated a direct possible correlation between the spinning content in methanolic extracts and cholinesterase, monoamine inhibitory activities because hexane and chloroform extract showed negligible saponin content.

4. Antiepileptic

effect: The anticonvulsant activity was evaluated using different extracts on seizures induced in rat models by maximal electroshock (MES) and pentylenetetrazole. In the test carried out, the methanolic extract has shown significant anticonvulsant effect which was anticipated by the observation of a 
decrease in the duration of the hind limb extension, clones and also the duration of stupor phase. There was a prolonged onset of the tonic clonic seizure induced by pentylenetetrazole in the groups treated with methanolic and aqueous extracts and mechanism behind the activity was GABAergic [55].

5. Antitussive effect: The methanolic extract of roots has been reported to possess antitussive. The activity was tested against sulfur dioxide $\left(\mathrm{SO}_{2}\right)$-induced cough in the mouse model [56]. The methanolic root extract administered at the concentration of $200,400 \mathrm{mg} / \mathrm{kg}$, and codeine phosphate was taken as a standard antitussive reference drug. Upon oral administration of methanol, extract displayed $40 \%$ and $58.5 \%$ inhibition of $\mathrm{SO}_{2}-$ induced cough at a dose of 200 and $400 \mathrm{mg} / \mathrm{kg}$ respectively. Antitussive effect produced was dose dependent for both extracts as well as standard drug which further supported the claims put forward by traditional medicine practitioners about the usefulness of $A$. racemosus in the treatment of cough.

\section{Antileshmanial} activity: Leishmaniasis can occur in diverse clinical forms such as cutaneous, mucosal, visceral leishmaniasis (VL, the most severe) and remain a major health problem in the tropical and subtropical areas, threatening almost 350 million people in 88 countries $[\mathbf{5 7}, \mathbf{5 8}]$. The viability of promastigotes after treatment with Racemoside A (2) was evaluated using a modified MTT assay [59]. The decreased formazan production in the promastigotes indicated that racemoside A (2) reduces the viability of the cells. Treatment with racemoside A (2) also demonstrated a dose-dependent removal of phagocytosed amastigotes. Racemoside $\quad$ A treated $L . \quad$ donovani promastigotes showed signs of programmed cell death, i.e. the flagellated promastigotes shrank and became aflagellated, oval or round with increased vacuoles. Phosphatidylserine was translocated from the inner side of the outer layer of the plasma membrane which is observed during cell death [60].

7. Anti-plasmodial activity: The ethyl acetate extract of the roots of $A$. racemosus has been tested for anti-plasmodial activity. The extract with yield value of $7.9 \%$ per $100 \mathrm{~g}$ 
have shown dose dependent inhibition of chloroquine resistant strain of Plasmodium falciparum (3D7) with an $\mathrm{IC}_{50}$ value of $29 \mu \mathrm{g} / \mathrm{mL}$ [61].

8. Anti-HIV activity: A. racemosus is also known to show immunomodulatory activity. Steroidal saponin glycosides (1924) have been reported from these extracts. Compound 19 isolated from the ethanolic extract exhibited the highest anti-HIV activity as compared to other saponin glycosides [35]. Glycoside 20 with two sugars exhibited weak anti-HIV activity and saponins with three sugar units (21-24) showed weak to no activity. Structurally similar compounds have been reported to have anti-HIV protease activity [62].

\section{Immunostimulant: Immunodeficie} ncy disorders are the group of disorders in which the body's defence system is compromised, making it to be less effective against foreign invaders. As a result, the person with an immunodeficiency disorder will have frequent infections that are generally more severe and remain longer than usual. Isolated polyhydroxylated steroidal sapogenin acids (13-15) were studied on the immune system of normal and cyclosporine-A induced immune-suppressed animals and has been found that compound is a potent immune system stimulator [30].

The study mainly focused on the lymphocytes and cytokines, since $\mathrm{T}$ \& B lymphocytes are the backbone of the immune system and modulation of Th1/Th2 immunity are important biological targets for immunostimulant [63]. Upon oral administration of the compounds there has been significant and dose dependent increased CD3 \& CD19 count and Th1/Th2 cytokines. Results obtained were comparable to levamisole, indicating that the compounds were potent immune system stimulator.

Steroidal saponins, shatavaroside A (26) and shatavaroside B (27), isolated from the methanolic extract of $A$. racemosus, and their immunomodulatory activity have been evaluated using polymorphonuclear leukocyte function test and some more sensitive assays such as nitroblue tetrazolium, nitrous oxide and chemiluminescence assays were used as a confirmatory test for the activity. The steroidal saponins 
isolated were found to be active at nano concentrations $(5 \mathrm{ng} / \mathrm{mL})$ and can act as a potent immunostimulant [37].

10. Hepatoprotective Activity: The hepato-protective activity of A.racemosus was evaluated against isoniazid-induced hepatotoxicity in male albino rats. Animals exposed to Isoniazide showed necrotic changes resulting in the release of hepatic enzymes aspartate aminotransferase, alanine aminotransferase, alkaline phosphatase and $\gamma$-glutamyl transpeptidase that mark liver injury. The increased level of aspatate aminotransferase and alanine amino transferase indicated increased permeability and hepatic cell damage. Restoration of glutathione levels in cases with isoniazide toxicity upon extract administration was observed [64]. Hepatoprotective activity was resultant of inhibited production of free radicals, acting as a scavenger and reducing the free radical generation via inhibition of hepatic CYP2E1 activity $[\mathbf{6 5}, \mathbf{1 1}]$.

In paracetamol induced liver injury in rats there is increased levels of SGOT, SGPT, serum bilirubin and serum alkaline phosphatase, upon treatment with the ethanolic roots extract and reversal in their levels indicating the hepatoprotective activity. There were depleted levels of catalase and superoxide dismutase which act as antioxidants and upon treatment with the extract there was an improvement in their levels [66].

11. Antibacterial activity: The root extracts of $A$. racemosus have been studied for antibacterial activity employing standard cylinder method. Microbes used were Bacillus subtilis, Staphylococcus aureus, Staphylococcus werneri, Pseudomonas

aeruginosa and Escherichia coli, Proteus mirabilis, Kleibsella pneumonia, Pseudomonas putida. Both gram-positive and gramnegative bacteria were sensitive to the extract. Ethanolic extract of concentration $100 \mathrm{mg} / \mathrm{ml}, 300 \mathrm{mg} / \mathrm{ml}$, $500 \mathrm{mg} / \mathrm{ml}$ were prepared and there antibacterial activity was comparable to reference standard drug Gentamycin $(25 \mu \mathrm{g})$. The gram positive bacteria were most affected by Staphylococcus aureus [67].

\section{Pregnancy:}

1. Antiabortifacient: The formulations containing $A$. 
racemosus roots

(eg.

Shatavari sidh ghrit) were

prescribed in the cases of threatened abortions ${ }^{68}$. The observed activity was due to the Shatavarin-I [69] (7). In vivo effect of shatavarin IV (12) i.e. saponin A4 on the uterine muscles was similar to the estrogen [70]. The polycyclic alkaloid asparagamine A (28) have been reported to possess an anti-oxytocic action [38] and showing an antiabortifacient affect.

2. Antenatal tonic: A capsule Sujat containing $A$. racemosus extract, in a clinical trial containing a group of 450 patients, reported that regular use of this capsule during antenatal period increases the fetal weight and decreases the occurrence of perinatal deaths [71]. There was reduction in the incidence of pregnancy induced hypertension (PIH). PGI2 and NO (nitric oxide) are the important vasodilators; a deficiency of these can lead to PIH. Essential fatty acid
GLA (Gamma linolenic acid) obtained from $A$. racemosus known to mediate the produce PGI2 in preference to $\mathrm{TXA}_{2}[71]$.

13. Anti-Ulcer: Acute gastric ulcers were induced in rat model by cold restraint stress, pyloric ligation, aspirin plus pyloric ligation, and duodenal ulcers induced by cysteamine. The protective activity of the extract was due to the increase in mucosal defensive factors like mucus secretion, cellular mucus, life span of cells and anti-oxidant effect. Satavari mandur an Ayurvedic preparation that containing $A$. racemosus given in the dose of $1.5 \mathrm{~g}$, twice daily for a month displayed noteworthy improvement in symptoms of peptic ulcer and healing of peptic ulcers was endoscopically verified [72]. A marked decrease in cell shedding and increase in mucin secretion indicated its predominant effect on mucosal defensive factors [16].

There was a significant reduction in ulcer index and reductions in the volume of gastric secretion upon treatment with crude extract in indomethacin treated rats. The reduction in gastric lesions was found to be comparable to standard 
Ranitidine. It has been concluded that $A$. racemosus have an antiulcerogenic activity. The activity was the result of inhibitory effect on release of gastric hydrochloric acid and protects gastric mucosal damage [73].

In humans, $A$. racemosus root powder is effective in chronic peptic ulcers. There was an increase in the lifespan of gastric mucosal epithelial cells, secretion and viscosity of gastric mucus [74].

14. Anti-diarrheal Activity: In the developing countries, diarrhoea is the reason for three-fourth of infant and childhood mortality [75]. The mortality rates were found to be high in children of less than five years of age. The use of oral dehydration therapy reduced mortality but chronic diarrhoea is still a life-threatening problem in the regions where malnutrition is a regular co-existing and complication factor. The extracts of $A$. racemosus were evaluated for its antidiarrheal activity in castor oil-induced diarrhoeal rats. The ethanolic and aqueous extracts have been shown to possess inhibitory activity against gastrointestinal tract motility after charcoal meal administration and PGE2 induced enteropooling, taking loperamide as a reference drug [12].

\section{Anticandidal}

Activity: Experimental findings suggested that methanol extracts possessed high anticandidal activity against different Candida species. The disc diffusion method was chosen for antifungal susceptibility tests taking fluconazole as a reference drug. Candida strains were isolated from vaginal thrush patients, and the species were identified using conventional tests. They observed zone of inhibition ranging from 13 to $16 \mathrm{~mm}$. The MIC (Minimum inhibitory concentration) values were between 2.5 to $0.312 \mathrm{mg} / \mathrm{ml}$, while $\mathrm{MFC}$ (Minimum fungicidal concentration) values ranged between 5 to $0.625 \mathrm{mg} / \mathrm{mL}$ [76].

\section{Anti-aflatoxigenic}

activity: Fourteen essential oils constituents were obtained from the biodeteriorated $A$. racemosus which were tested as individual component as well as in combination their antiaflatoxigenic activity. Constituents obtained were thymol (55), eugenol (56), menthol (57), gerayl acetate (58), linalool (59), $\beta$-asarone (60), 1, 8-cineol (61), E-citral (62), $\beta$ caryophyllene (63), $\alpha$-pinene (64), 
carvone (65), p-cymene (66), carvacrol (67), ocimene (68) (figure 3). Among 14 constituents, thymol and eugenol showed potent fungicidal activity since both caused blocking of the growth of spores and the rest of essential oil constituents showed moderate antifungal activity [44].

17. Cardio protective effects: Abana, herbomineral formulation manufactured by Himalayan drugs, have been found useful in controlling hypercholesterolemia, prevention and management of coronary heart disease. Abana was given in normal as well as in cases of essential hypertension and angina pectoris and was found to reduce the total cholesterol and triglyceride levels. There was an observed significant increase in high-density lipoprotein cholesterol levels [77].

The lipid-lowering effects of $A$. racemosus root extract in hypercholesteremic rats was demonstrated and the investigation revealed that primary reason of antihypercholestrolemic effect was increased excretion of cholesterol, neutral sterols, bile acid and increase in hepatic bile acid content. Increased HMG-CoA reductase activity in hypercholesteremic rats upon treatment with $A$.

racemosus root powder was

powder.

Interestingly, normocholesteremic animals under $A$. racemosus treatment, exhibited no significant variations either in excretion of cholesterol, neutral sterols, bile acid, hepatic cholesterol and bile acid content. Significant increase in plasma HDL-C levels with a concurrent decline in the plasma cholesterol level and an improvement in the atherogenic index of hypercholestrolemic test animals clearly indicated the beneficial role of root administration in hypercholesteremic animals. The reduction in the levels of HDL-C is an indicative of high risk of cardiovascular disease, so improvement in its levels gives cardioprotective activity [15].

\section{Neurodegenerative}

disorders: EuMil, polyherbal formulation consisting of standardized extracts has been used as anti-stress agent to ease the various aspects of stress related disorders. The extract showed normalization in the elevated levels of NA (nor-epinephrine), DA (dopamine), 5HT (5-hydroxy tryptamine) concentrations, which 
were increased by chronic electroshock stress. Decrease in neurochemical levels in the brain indicates the effectiveness of the formulation in neurological disorders [78]. It has been found to be effective in neurodegenerative disorders like Alzheimer's and Parkinson's disease.

The potential of methanolic root extract roots against kainic acid induced hippocampal and striatal neuronal damage in mice have been evaluated [79]. Upon injection of kainic acid in intra-hippocampal and intra-striatal region in anesthetized mice leads to the production of excitotoxic lesions in the brain. After the injection of kainic acid, there was an observed impairment of hippocampus and striatal regions of the brain with an increased lipid peroxidation, increased protein carbonyl content, decreased glutathione peroxidase activity and reduction in the glutathione content.

Glutathione is an important antioxidant which is a nucleophilic scavenger of toxic compounds and also act as substrate in the glutathione peroxidase mediated destruction of hydro-peroxides which would otherwise accumulate to toxic levels in brain tissues. The mice treated with methanolic rootextract showed an enhancement in glutathione peroxidase activity, glutathione content, reduction in membrane lipid peroxidation and protein carbonyl. They concluded, plant extract plays the role of an antioxidant by attenuating free radical induced oxidative damage. The oxidative damage protection of the hippocampal and striatal regions of the brain is useful in the neurodegnerative disease [79].

19. Anti-cancer property: The root extract was shown to have a protective effect in the mammary cell carcinoma [80]. Steroidal components of the $A$. racemosus were investigated for the apoptotic activity and inferred to have the capacity to tumor cell death [81]. Natural products have long been used for treatment against cancer. There are at least 10000 species of plants, documented to have anti-cancerous properties. As described by Shankar et.al the isolated shatavarin IV along with AR-2B containing $5.05 \%$ shatavarin IV showed potent cytotoxicity. It showed increase in non-viable cell count when compared to untreated mice of group in the study. Hence 
from various in vitro and in vivo models it can be concluded that the root extract of the plant which contains shatavari IV fraction exhibits significant activity against cancer cells.

Choloroform/methanol (1:1) extract of fresh root of $A$. racemosus has been reported to reduce the tumor incidence in female rats treated with 7, 12 dimethyl benza. This action is suggested to be medicated by virtue of mammotropic and/ or lactogenic, influence of $A$. racemosus on normal as well as estrogen primed animals, which renders the mammary epithelium refractory to the carcinogen (12).

Anticancer activity of shatavarins (containing Shatavarin IV)

which was isolated from the roots of have been evaluated by MTT assay using MCF-7 (human breast cancer), HT-29 (human colon adenocarcinoma) and A-498 (human kidney carcinoma) cell lines and in vivo experimental model of Ehrlich ascites carcinoma (EAC) tumor bearing mice. The experimental results suggested that the extract (containing Shatavarin IV) possess potent anti-cancer activity [82].
Safety profile: The safety profiling of $A$. racemosus was performed extensively and have been found to be safe at therapeutic dose but showed toxicity at much higher doses. Itsmethanolic root extract has been administered to Charles-foster strain albino rats $100 \mathrm{mg} / \mathrm{kg} /$ day for 60 days [83].

In prenatal study the extract treated group of rats caused increased resorption of fetuses, swelling of legs and slow growth of fetal body and placental parts. In the postnatal study it was observed that the group of rats to which the extract was administered showed a decreased number of pups per litter, increased mortality of pups per litter and delayed the various developmental parameters when compared to control group, although, it does not show teratogenicity at clinical dose.

At higher dose teratogenic effect were observed therefore highlighting that it can be given during the pregnancy but with a caution. In another study conducted using Charles-foster rats as test animals, were treated with aqueous extract of roots observed that there was no morbidity or mortality in test animals at any given dose. There was an observed increase in the serum creatinine level at a dose of 4000 $\mathrm{mg} / \mathrm{kg}$ and $5000 \mathrm{mg} / \mathrm{kg}$ in acute study, elevated level of SGPT activity at a dose of $50,150,500$ and $1000 \mathrm{mg} / \mathrm{kg}$ and decreased blood urea nitrogen level at 500 $\mathrm{mg} / \mathrm{kg}$ as compared to control. The 
histopathological changes were observed in the test animals and shown mild fatty change at $500 \mathrm{mg} / \mathrm{kg}$ and $1000 \mathrm{mg} / \mathrm{kg}$ dose.

A. racemosus is well tolerated in Charles foster rats in both acute and sub-acute toxicity study but showed some biochemical and histopathological changes [84]. Still there is a need to find the chronic toxicity study and its mechanism in Charles foster rats.

Drugs under marketing: According to National Medicinal Plant Board, 2003 the demand for $A$ racemosus was 10,924.7 tonnes in 2001-2002 which was increased up to the level of $16,658.5$ tonnes in 2004 2005 indicating the annual growth rate of its demand is $15 \%$ [85]. A. racemosus is not only a research oriented plant but as outlined by its marketing status it displays broad economic importance worldwide. A lot of formulations using $A$. racemosus extracts have been reported and mentioned in Table 3.

Himalayan herbal health care, currently manufactures formulations containing significant amount of extract of the plant (Table 3). The substantial amount of extract in the formulations has been used by $A$. racemosus.

Conservation: The active principle is the main constituent of the medicinal plant which is of interest, so cultivating the superior clones which can be identified by molecular marker techniques and chemo- profiling are the techniques for improving the active principle contents.

The micro propagation method was developed as an efficient in vitro protocol for the micropropagation of $A$. racemosus through the axillary branching method [110]. The cell suspension culture system is a more efficient method for the large scale production of secondary metabolites from plant cells.

Synthesis of sarsasapogenin in the callus cultures of $A$. racemosus has been reported [111] than in the later studies, HPTLC showed that the highest amount of sarsasapogenin $(0.133 \%)$ was present in shoot tumor followed by root callus $(0.127 \%)$ and these levels were 2.59 and 2.5 times higher than the natural roots respectively [110]. In -vitro propagation of $A$. racemosus was carried out using shoot apex and nodal explants and plants were transferred to the fields after five weeks of hardening [109].

Callus cultures of $A$. racemosus were developed and saponin content was determined. It was observed that maximum accumulation in root calli and nodal was $10.38 \pm 0.14 \mathrm{mg} / \mathrm{g}$ of callus and $7.69 \pm$ $0.136 \mathrm{mg} / \mathrm{g}$ of callus respectively after 60 days of accumulation. In vitro cultures showed 20 fold increases in shatavarin levels as compared to the wild type roots [104]. 
Table 3: Asparagus racemosus Containing Formulations

\begin{tabular}{|c|c|c|c|c|}
\hline $\begin{array}{l}\text { S. } \\
\text { No. }\end{array}$ & Drug & Content of $A$. racemosus & Medicinal property & Reference \\
\hline 1 & Abana ${ }^{\circledR}$ & $\begin{array}{l}10 \mathrm{mg} \text { Shatavari root } \\
\text { extract per tablet }\end{array}$ & $\begin{array}{l}\text { Hyperlipidemic conditions } \\
\text { Mild to moderate hypertension } \\
\text { Adjuvant in the angina with cardiac risk factor } \\
\text { Inhibition of platelet aggregation }\end{array}$ & $\begin{array}{l}6 \\
86 \\
87 \\
88\end{array}$ \\
\hline 2 & Diabecon® & $\begin{array}{l}20 \mathrm{mg} \text { Shatavari root } \\
\text { extract per tablet }\end{array}$ & $\begin{array}{c}\text { Monotherapy in non-insulin-dependent diabetes } \\
\text { mellitus } \\
\text { Adjuvant to other oral antidiabetic drugs } \\
\text { NIDDM with hyperlipidemia } \\
\text { Early retinopathy } \\
\text { Microalbuminuria } \\
\text { Promotes } \beta \text {-cell repair/ regeneration and } \\
\text { increases the C-peptide level }\end{array}$ & $\begin{array}{l}89 \\
\\
90 \\
91 \\
92 \\
93 \\
94\end{array}$ \\
\hline 3 & EveCare® & $\begin{array}{l}32 \mathrm{mg} \text { Shatavari root } \\
\text { extract per } 5 \mathrm{ml} \text { syrup }\end{array}$ & $\begin{array}{l}\text { Dysmenorrhea } \\
\text { Menorrhagia } \\
\text { Metrorrhagia } \\
\text { Oligomenorrhea }\end{array}$ & $\begin{array}{l}95 \\
96 \\
97 \\
98\end{array}$ \\
\hline 4 & Geriforte ${ }^{\circledR}$ & $\begin{array}{l}20 \text { mg Shatavari root } \\
\text { powder per tablet }\end{array}$ & $\begin{array}{l}\text { Geriatric stress } \\
\text { Generalized anxiety disorders } \\
\text { Stress related anxiety } \\
\text { Prolonged illness and convalescence }\end{array}$ & $\begin{array}{c}99 \\
100 \\
101 \\
102\end{array}$ \\
\hline 5 & Himplasia ${ }^{\circledR}$ & $\begin{array}{l}80 \mathrm{mg} \text { Shatavari root } \\
\text { powder per tablet }\end{array}$ & Benign prostatic hyperplasia & 103 \\
\hline 6 & Lukol@ & $\begin{array}{l}40 \text { mg Satavari root } \\
\text { extract per tablet }\end{array}$ & $\begin{array}{c}\text { Leukorrhea } \\
\text { Malaise } \\
\text { Backache associated with leukorrhea and Pelvic } \\
\text { inflammatory disease }\end{array}$ & $\begin{array}{l}104 \\
105 \\
106\end{array}$ \\
\hline 7 & Menosan®® & $\begin{array}{l}110 \mathrm{mg} \text { Satavari root } \\
\text { extract per tablet }\end{array}$ & $\begin{array}{l}\text { Natural menopause } \\
\text { Surgical menopause }\end{array}$ & $\begin{array}{l}107 \\
108\end{array}$ \\
\hline 8 & Renalka ${ }^{\circledR}$ & $\begin{array}{c}50 \mathrm{mg} \text { shatavari root } \\
\text { extract per } 5 \mathrm{~mL} \text { of syrup }\end{array}$ & $\begin{array}{c}\text { Burning micturition } \\
\text { Cystitis, Recurrent Urinary Tract Infection, } \\
\text { Dysuria, Hematuria }\end{array}$ & $\begin{array}{c}7 \\
109\end{array}$ \\
\hline
\end{tabular}

\section{CONCLUSION}

A. racemosus is an important medicinal plant having traditional importance as it is used in the indigenous system of medicines like Ayurveda, Sidha, and Unani. Traditional practices are proven by various experimental and scientific studies. This in both healthcare and trade. Considerable work has been done to explore the biological activity and medicinal applications of the plant, still there are available countless possibilities of pharmacological applications which needs to be explored.

depicts the plant with tremendous potential 
The plant has numerous therapeutic application viz. antioxidant, diuretic, antidepressant, antiepileptic, antitussive, anti-HIV, immunostimulant, hepatoprotective, cardio-protective, antibacterial, anti-ulcerative, neurodegenerative. The major studies were reported using extracts of the plant; still the active principle involved behind these activities needs to be explored. Formulations containing $A$. racemosus as the major ingredient against numerous disorders indicate its economic and therapeutic importance worldwide. The safety profile analysis showed that the $A$. racemosus is safe in therapeutic doses and can be used during pregnancy with a caution. As the value of medicinal plants depends on the active principle present in it, so the uniformity in quality as well as the quantity of planting material is of paramount importance.

Consistency can be achieved by utilizing the biotechnological approaches like micropropagation and callus culture. Furthermore, the optimization of environmental conditions and the development of appropriate agro techniques would enhance the quality and quantity of the overall production, thereby assuring of high quality and having phytochemicals in optimum yields.

This in turn would encourage farmers to undertake commercial cultivation of $A$. racemosus thus curbing the overexploitation of this plant in the wild and thereby complement the conservation process.

Conflict of interests: The authors have declared no conflict of interests

\section{REFERENCES}

[1] Kirtikar, Basu. Indian medicinal plants. Dehradun, India: Bishen Singh Mahendra Pal Singh 1985.

[2] Bopana N and Saxena S: Asparagus racemosus-Ethnopharmacological evaluation and conservation needs. J Ethnopharmacol 2007; 110:1-15.

[3] Goyal R, Singh Jand Lal H: Asparagus racemosus--an update. Indian J Med Sci 2003; 57:408-414.

[4] Chawla A, Chawla P and Mangalesh R.: Asparagus racemosus (Wild): Biological Activities \& its Active Principles. Indo-Global J Pharm Sci 2011; 2:113-120.

[5] Gomase V and Sherkhane A: Isolation, structure elucidation and biotransformation studies on secondary metabolites from Asparagus racemosus. Int J Microbiol Res 2010; 2:07-09.

[6] Venkataramaiah $\mathrm{H}$ : Double-blind comparative clinical trial of Abana and Simvastatin in Hyperlipidaemia. Insertion in Stroke Feb-Mar 2002.

[7] Sahu M, Gupta S and Srivastava P: Effect of Renalka syrup in Urinary Tract Infection. Indian Pract 2002; 55:101-106. 
[8] Dartsch PC: The Potential of Asparagus- $\mathrm{P}{ }^{\circledR}$ to Inactivate Reactive Oxygen Radicals. Phytother Res 2008; 22:217-222.

[9] Sharma M, Sharma A and Kumar A: Vital medicine Asparagus racemosus wild. Curr Trends Biotechnol Pharm 2012; 6:210-221.

[10] Hussain A, Ahmad MP, Wahab S, Sarfaraj Hussain M and Ali M: A Review on Pharmacological and Phytochemical Profile of Asparagus racemosus Wild. Pharmacologyonline 2011; 3:1353-1364.

[11] Singla R, Kaur R, Arora S and Jaitak $\mathrm{V}$ : In-vitro antimutagenic activity of Asparagus $\quad$ racemosus- An Ayurvedic medicinal plant. Am J Drug Discovery Dev 2013; 1-7 DOI: 10.3923/ajdd.2013.

[12] Venkatesan $N$, Thiyagarajan $V$, Narayanan S, Arul A, Raja S and Gurusamy S: Anti-diarrhoeal potential of Asparagus racemosus wild root extracts in laboratory animals. J Pharm Pharm Sci 2005; 8:39-46.

[13] Potduang B, Meeploy M, Giwanon R, Benmart $\mathrm{Y}$, Kaewduang $\mathrm{M}$ and Supatanakul W: Biological activities of Asparagus racemosus. Afr $\mathrm{J}$ Tradit Complement Alter Med 2008; 5:230-237.

[14] Pharmacopoeia I. The Indian pharmacopoeia commission. Central Indian Pharmacopoeia Laboratory,
Ministry of Health and Family Welfare, Govt of India, Sector 2007; 23.

[15] Visavadiya NP and Narasimhacharya A: Asparagus root regulates cholesterol metabolism and improves antioxidant status in hypercholesteremic rats. Evid Based Complement Alter Medicine 2009; 6:219-226.

[16] Goel R and Sairam K: Anti-ulcer drugs from indigenous sources with emphasis on Musa sapientum, tamrahbasma, Asparagus

racemosus and Zingiber officinale. Indian J Pharmacol 2002; 34:100110.

[17] Wiboonpun N, Phuwapraisirisan $\mathrm{P}$ and Tip-pyang S: Identification of antioxidant compound from Asparagus racemosus. Phytother Res 2004; 18:771-773.

[18] Kala CP: Aboriginal uses and management of ethnobotanical species in deciduous forests of Chhattisgarh state in India. J Ethnobiol Ethnomed 2009;5: 1-9.

[19] Kundu M, Mazumder R, Kushwaha M, Chakraborthy G and Kundu M: Standardization profiles of roots of Asparagus racemosus wild. Pharmacologyonline 2011; 3:587592.

[20] $<$ http://www.biorenesance.cz/biorene sance/eshop/462-1-Byliny-A-Z-E- 
shop-herbar>. as downloaded on 22october-2013.

[21] $<$ http://www.allthingshealing.com/He rbalism/Asparagus-Boon-for-

Women/10740>. As downloaded on 22-october-2013.

[22] Hayes PY, Jahidin AH, Lehmann R, Penman K, Kitching W and De Voss JJ: Asparinins, asparosides, curillins, curillosides and shavatarins: structural clarification with the isolation of shatavarin $\mathrm{V}$, a new steroidal saponin from the root of Asparagus racemosus. Tetrahedron Lett 2006; 47:8683-8687.

[23] Negi JS, Singh P, nee Pant GJ and Rawat M: High performance liquid chromatographic analysis of derivatized sapogenin of Asparagus (RP-HPLC analysis of derivatized sapogenin of Asparagus). J Med Plants Res 2011; 5:1900-1904.

[24] Penumajji S, Bobbarala V and Naidu $\mathrm{KC}$ : Extraction and optimization of molecular marker compounds from Asparagus racemosus using HPLC with ELS detector. J Pharma Res 2010; 3:159-162.

[25] Thakur M, Connellan P, Deseo MA., Morris C., Praznik W., Loeppert R., Dixit V. Characterization and in vitro immunomodulatory screening of fructo-oligosaccharides of Asparagus racemosus Wild. Int J Biol Macromol 2011; 50: 77-81.
[26] Handa SS, Suri OP, Gupta VN, Suri KA, Satti NK, Bhardwaj V, Bedi KL, Khajuria A, Kaul A and Parikh GG: Process for the isolation of novel oligospirostanoside. US patent US6670459.; 2003.

[27] Mandal D, Banerjee S, Mondal NB, Chakravarty AK and Sahu NP: Steroidal saponins from the fruits of Asparagus racemosus. Phytochemistry 2006; 67:1316-1321.

[28] Kumeta Y, Maruyama T, Wakana D, Kamakura $\mathrm{H}$ and Goda $\mathrm{Y}$ : Chemical analysis reveals the botanical origin of shatavari products and confirms the absence of alkaloid asparagamine $\mathrm{A}$ in Asparagus racemosus. $\mathrm{J}$ Nat Med 2012; 67:1-6.

[29] Hayes PY, Jahidin AH, Lehmann R, Penman K, Kitching W and De Voss JJ: Steroidal saponins from the roots of Asparagus racemosus. Phytochemistry 2008; 69:796-804.

[30] Sharma P, Chauhan PS, Dutt P, Amina M, Suri KA, Gupta BD, Suri OP, Dhar KL, Sharma D and Gupta $\mathrm{V}$ : A unique immuno-stimulant steroidal sapogenin acid from the roots of Asparagus racemosus. Steroids 2011; 76:358-64.

[31] Ahmad S, Ahmad S and Jain P: Chemical examination of Shatavari (Asparagus racemosus). Bull Medico Ethnobotanical Res 1991; 12:157160. 
[32] Khare CP: Indian medicinal plants: an illustrated dictionary. Heidelberg: Springer Verlag; 2007.

[33] Singh J and Tiwari H: Chemical examination of roots of Asparagus racemosus. J Indian Chem Soc 1991; 68:427-428.

[34] Bose S, Show S, Hazra M and Sarkar T: Comparative study of Antioxidant Activity of Herbal Drugs and their Formulations using Asparagus racemosus and Centella asiatica. Am J PharmTech Res 2012; 2:391-398.

[35] Sabde S, Bodiwala HS, Karmase A, Deshpande PJ, Kaur A, Ahmed N, Chauthe SK, Brahmbhatt KG, Phadke RU, Mitra D, Bhutani KK and Singh IP: Anti-HIV activity of Indian medicinal plants. J Nat Med 2011; 65:662-669.

[36] Sharma U, Saini R, Kumar N and Singh B: Steroidal saponins from Asparagus racemosus. Chem Pharm Bull 2009; 57:890-893.

[37] Sharma U, Kumar N, Singh B, Munshi RK and Bhalerao S: Immunomodulatory active steroidal saponins from Asparagus racemosus. Med Chem Res 2009; 121:1-7.

[38] Sekine T, Ikegami F, Fukasawa N, Kashiwagi Y, Aizawa T, Fujii Y, Ruangrungsi $\mathrm{N}$ and Murakoshi $\mathrm{I}$ : Structure and relative stereochemistry of a new polycyclic alkaloid, asparagamine A, showing antioxytocin activity, isolated from Asparagus racemosus. J Chem Soc Perkin Transact 1 1995:391-393.

[39] $39 . \quad$ Murakoshi, Isamu, Fujii and Juichi: Extraction of novel polycyclic alkaloid from Asparagus racemosus Wild for therapeutic use. Patent-Japan Kokai Tokkyo Koho-07 330, 774: 6PP- (1995) (TSUMURA \& CO JAPAN) 1995.

[40] Sekine T, Fukasawa N, Murakoshi I and Ruangrungsi N: A 9, 10dihydrophenanthrene from Asparagus racemosus. Phytochemistry 1997; 44:763-764.

[41] Saxena V and Chourasia S: A new isoflavone from the roots of Asparagus racemosus. Fitoterapia 2001; 72:307-9.

[42] Saxena VK, Choubasia and Sangeeta: 5-Hydroxy-3,6,4'-trimethoxyflavone7-O- $\beta$-D-glucopyranosyl[ $1 \rightarrow 4]$-O- $\alpha$ D-xylopyranoside from leaves of Asparagus racemosus. J Inst Chem (India) 2000; 6:211-213.

[43] Gyawali R and Kim KS: Bioactive volatile compounds of three medicinal plants from nepal. Kathmandu Uni J Sci Eng Technol 2011; 8:51-62.

[44] Mishra PK, Singh P, Prakash B, Kedia A, Dubey NK and Chanotiya CS: Assessing essential oil components as plant-based preservatives against fungi that deteriorate herbal raw materials. Int 
Biodeterior Biodegrad 2013; 80:1621.

[45] Negi JS, Singh P, Nee Pant GJ, Rawat MSM and Pandey H: Variation of Trace Elements Contents in Asparagus racemosus (Wild). Biol Trace Elem Res 2010; 135:275-282.

[46] Kamat JP, Boloor KK, Devasagayam $\mathrm{T}$ and Venkatachalam S: Antioxidant properties of Asparagus racemosus against damage induced by $\gamma$-radiation in rat liver mitochondria. J Ethnopharmacol 2000; 71:425-435.

[47] Kamat $\mathrm{J}$ and Devasagayam $\mathrm{T}$ : Tocotrienols from palm oil as potent inhibitors of lipid peroxidation and protein oxidation in rat brain mitochondria. Neurosci Lett 1995; 195: 179-182.

[48] Kamat JP and Devasagayam T: Methylene blue plus light-induced lipid peroxidation in rat liver microsomes: inhibition by nicotinamide (vitamin B3) and other antioxidants. Chem Biol Interact 1996; 99:1-16.

[49] Bhatnagar M, Sisodia SS andBhatnagar R: Antiulcer and antioxidant activity of Asparagus racemosus Wild and Withania somnifera Dunal in rats. Ann N Y Acad Sci 2005; 1056:261-278.

[50] Karmakar U, Biswas S, Chowdhury A, Raihan S, Akbar M, Muhit M and Mowla R. Phytochemical
Investigation and Evaluation of Antibacterial and Antioxidant Potentials of Asparagus racemosus. Int J Pharmacol 2012; 8:53-57.

[51] Kumar MCS, Udupa A, Sammodavardhana K, Rathnakar U, Shvetha U and Kodancha G: Acute toxicity and diuretic studies of the roots of Asparagus racemosus wild in rats. West Indian Med J 2010; 59:3-5.

[52] Dhingra $D$ and Kumar V: Pharmacological Evaluation for Antidepressant-like Activity of Asparagus racemosus Wild. In mice. Pharmacologyonline 2007; 3:133-152.

[53] Singh GK, Garabadu D, Muruganandam AV, Joshi $\mathrm{VK}$ and Krishnamurthy S: Antidepressant activity of Asparagus racemosus in rodent models. Pharmacol Biochem Behav 2009; 91:283-290.

[54] Meena J, Ojha R, Muruganandam A and Krishnamurthy S: Asparagus racemosus competitively inhibits in vitro the acetylcholine and monoamine metabolizing enzymes. Neurosci Lett 2011; 503:6-9.

[55] Jalalpure S, Bagewadi V and Shaikh I: Antiepileptic effect of Asparagus racemosus root extracts. J Trop Med Plants 2009; 10:157-161.

[56] Mandal SC, Kumar CK A, Mohana Lakshmi S, Sinha S, Murugesan T, Saha B and Pal M. Antitussive effect of Asparagus racemosus root against 
sulfur dioxide-induced cough in mice.

Fitoterapia 2000; 71:686-689.

[57] Chava A, Chatterjee $M$ and Mandal $\mathrm{C}$ : O-Acetyl sialic acids in parasitic diseases. Handbook of Carbohydrate Engineering 2005:71-98.

[58] Murray HW, Berman JD, Davies CR and Saravia NG: Advances in leishmaniasis. The Lancet 2005; 366:1561-1577.

[59] Dutta A, Ghoshal A, Mandal D, Mondal NB, Banerjee S, Sahu NP and Mandal C: Racemoside A, an antileishmanial, water-soluble, natural steroidal saponin, induces programmed cell death in Leishmania donovani. J Med Microbiol 2007; 56:1196-1204.

[60] Koonin EV and Aravind L: Origin and evolution of eukaryotic apoptosis: the bacterial connection. Cell Death Differ 2002; 9:394-404.

[61] Kaushik NK, Bagavan A, Rahuman AA, Mohanakrishnan D, Kamaraj C, Elango G, Zahir AA and Sahal D. Antiplasmodial potential of selected medicinal plants from Eastern Ghats of South India. Exp Parasito 2013; 134:26-32.

[62] Yang XW, Zhao J, Cui YX, Liu XH, Ma CM, Hattori M and Zhang LH: Anti-HIV-1 protease triterpenoid saponins from the seeds of Aesculus chinensis. J Nat Prod 1999; 62:15101513.
[63] Glavin GB, Paré WP, Sandbak T, Bakke HK and Murison R. Restraint stress in biomedical research: an update. Neurosci Biobehav Rev 1994; 18:223-49.

[64] Ergul Y, Erkan T, Uzun H, Genc H, Altug $\mathrm{T}$ and Erginoz E: Effect of vitamin $\mathrm{C}$ on oxidative liver injury due to isoniazid in rats. Pediatr Int 2010; 52 69-74.

[65] Palanisamy $\mathrm{N}$ and Manian $\mathrm{S}$ : Protective effects of Asparagus racemosus on oxidative damage in isoniazid-induced hepatotoxic rats: an in vivo study. Toxicol Ind Health 2011; 28:238-244.

[66] Rahiman O, Kumar MR, Mani TT, Niyas KM, Kumar BS, Phaneendra P and Surendra B: Hepatoprotective Activity of Asparagus Racemosus Root On Liver Damage Caused By Paracetamol in Rats. Indian J Novel Drug Delivery 2011; $3: 112-7$

[67] Ravishankar K, Kiranmayi G, Lalitha TM, Priyanka T, Ranjith T, Someswarao S, Raju VRK and Divya A: Preliminary phytochemical screening and in-vitro antibacterial activity on Asparagus racemosus root extract. Int J Pharm Chem Biol Sci 2012; 2:117-123.

[68] Garg D, Agarwal J and Garg D. Shatawar. Dhanvantri 1971; 45:20820. 
[69] Dev S: Ancient-modern concordance in Ayurvedic plants: some examples. Environ Health Perspect 1999; 107:783-789.

[70] Gaitonde $B$ and Jetmalani M: Antioxytocic action of saponin isolated from Asparagus racemosus Willd (Shatavari) on uterine muscle. Arch Int Pharmacodyn Thér 1969; 179:121129.

[71] Bhasale L, Padia D, Malhotra H, Thakkar D, Palep H and Algotar K: Capsule" Surat" for comprehensive antenatal care and prevention of pregnancy induced hypertension. The Lancet 1994; 343:619-629.

[72] Sairam K, Priyambada S, Aryya N and Goel R: Gastroduodenal ulcer protective activity of Asparagus racemosus: an experimental, biochemical and histological study. J Ethnopharmacol 2003; 86:1-10.

[73] Bhatnagar $M$ and Sisodia $S$ : Antisecretory and antiulcer activity of Asparagus racemosus Wild. against indomethacin plus pyloric ligation-induced gastric ulcer in rats. J Herbal Pharmacother 2006; 6:13-20.

[74] Mangal A, Panda D and Sharma M: Peptic ulcer healing properties of Shatavari (Asparagus racemosus Wild.). Indian $\mathrm{J}$ Tradit Knowl 2006; 5:229-236.

[75] Jousilahti P, Madkour S, Lambrechts $\mathrm{T}$ and Sherwin E: Diarrhoeal disease morbidity and home treatment practices in Egypt. Public Health 1997; 111:5-10.

[76] Uma B, Prabhakar K and Rajendran S: Anticandidal activity of Asparagus racemosus. Indian J Pharm Sci 2009; 71:342-343.

[77] Tiwari A, Agarwal A, Shukla S and Dubey G: Favourable effect of Abana on lipoprotein profiles of patients with hypertension and angina pectoris. Altern Med 1990; 3:139-42.

[78] Bhattacharya A, Muruganandam A, Kumar V and Bhattacharya S: Effect of poly herbal formulation, EuMil, on neurochemical perturbations induced by chronic stress. Indian J Exp Biol 2002; 40:1161-1163.

[79] Parihar $M$ and Hemnani $T$ : Experimental excitotoxicity provokes oxidative damage in mice brain and attenuation by extract of Asparagus racemosus. J Neural Transm 2004; 111:1-12.

[80] Rao AR: Inhibitory action of Asparagus racemosus on DMBAinduced mammary carcinogenesis in rats. Int J Cancer 1981; 28: 607-610.

[81] Bhutani KK, Paul AT, Fayad W and Linder S: Apoptosis inducing activity of steroidal constituents from Solanum xanthocarpum and Asparagus racemosus. Phytomedicine 2010; 17: 789-793. 
[82] Mitra SK, Prakash NS and Sundaram R: Shatavarins (containing Shatavarin IV) with anticancer activity from the roots of Asparagus racemosus. Indian J Pharmacol 2012; 44: 732-736.

[83] Goel R, Prabha T, Kumar MM, Dorababu $M$ and Singh G: Teratogenicity of Asparagus racemosus Wild. root, a herbal medicine. Indian J Exp Biol 2006; 44: 570-573.

[84] Chanda D, Patider K, Pal A, Luqman S, Bawankule DU, Mani DN and Yadav NP: Safety evaluation of Asparagus $\quad$ racemosus: a commonly used herb of Ayurvedic Medicine in Charles Foster rats. Nature Precedings, doi:101038/npre2012692112012.

[85] Board. NMP. $<$ http://www.balkanherbs.org/Medici nalPlantsand ExtractsNo8.pdf>. 2003.

[86] Verma $\mathrm{S}$ and Bordia A: Effect of Abana (An Indigenous Herbal Compound) in Patients of Mild and Moderate Hypertension. Probe 1992; 31:177-179.

[87] Dubey G, Agrawal A, Srivastava Sr $\mathrm{V}$, Agrawal $\mathrm{U}$ and Udupa $\mathrm{K}$ : Management of Risk Factors of Coronary Heart Disease with an Indigenous Compound-Abana (A Controlled Study). Probe 1985; 25:146.
[88] Verma S and Bordia A: Effect of an Indigenous Herbal Compound Abana on Fibrinolysis and Platelet Aggregation. Probe 1991; 31:51-54.

[89] Ganguly D, Banerjee T, Singh A and Mitra S: Effect of Diabecon (D-400), an Ayurvedic Herbomineral Formulation in Non-Insulindependent Diabetes Mellitus Cases. The Antiseptic 1995; 92:460-462.

[90] Kohli K, Shilin G and Kolhapure S: Evaluation of the clinical efficacy and safety of Diabecon in NIDDM. The Antiseptic 2004; 101:487-494.

[91] Mitra S, Seshaiah V, Agrawal J, Maji D, Yajnik V, Kumar KMP and Singh A: Multicentric trial of Diabecon-a herbomineral preparation on lipid profile in diabetes mellitus. Int $\mathrm{J}$ Diabetes Dev Countries 1996; 16:8789.

[92] Kant S, Sahu M and Sharma S: Effect of Diabecon (D-400), an ayurvedic herbomineral formulation on diabetic retinopathy. Indian J Clin Pract 2002; 12: 49-56.

[93] Yajnik V, Acharya $\mathrm{H}$ and Yajnik N: Efficacy of D-400 in NIDDM Patients having Microalbuminuria. Indian Pract 1995; 48:851-854.

[94] Maji D and Singh A: Effect of Diabecon (D-400), an ayurvedic herbal formulation on plasma insulin and C-peptide levels in NIDDM patients. Indian Pract 1996; 1: 69-73. 
[95] Swarup A and Umadevi K:

Evaluation of EveCare in the Treatment of Dysmenorrhoea and Premenstrual Syndrome. Obstet Gynaecol Today 1998; 6:369-372.

[96] Sarda N, Prasad S and Mitra S: EveCare capsule:Evaluation of efficacy and safety in menorrhagia. Med Update 2007; 15: 26-32.

[97] Mitra S, Sunitha A, Kumar V, Pooranesan R and Vijayalakshmi M: Evecare (U-3107) as a Uterine TonicPilot Study. Indian Pract 1998; 51:269-272.

[98] Venugopal S: Effect of EveCare in Oligomenorrhoea. Antiseptic 1998; 95:329-330.

[99] Ghosh S and Mitra D: A clinical evaluation of Geriforte in common stressful illness. Curr Med Pract 1985; 8:201-205.

[100] Shah L, Mazumdar K, Nayak P, Shah A, Shah N and Parkar S: Clinical evaluation of Geriforte in patients of generalized anxiety disorder. Bombay Hosp J 1990; 32: 29.

[101] Boral G, Bandopadyaya G, Boral A, Das $\mathrm{N}$ and Nandi P: Geriforte in anxiety neurosis. Indian J Psychiatry 1989; 31: 258 .

[102] Vaidya M: Tissue RegeneratorGeriforte. Probe 1979; 1: 24.

[103] Sahu M and Kulkarni KS: Clinical evaluation of Himplasia in Benign Prostatic Hyperplasia: An Open
Clinical Trial. Med Update 2003; 11:75-8.

[104] Bhatnagar P and Bhatnagar J: Lukol in leucorrhoea. Probe 1984; 23: 105-106.

[105] Dabak S, Burute $P$ and Dani S: Lukol in the treatment of leucorrhoea and abnormal uterine bleeding following MTP, IUCD and Tubectomy. Probe 1982; 21: 101104.

[106] Tewiri $P$ and Kab Suliw Kulkiroi M: A study of lukol in leucorrhoea, pelvic inflammatory diseases and dysfunctional uterine bleeding. Ancient Sci of Life 2001; 21:139150.

[107] Sarkar A, Giri S and Kolhapure S: Evaluation of efficacy and safety of Menosan in the management of postmenopausal syndrome: A prospective, randomized, double blind, placebo-controlled, phase III clinical trial. Med Update 2004; 12 : 41-51.

[108] Singh $S$ and Kulkarni KS: Evaluation of the efficacy and safety of Menosan in post-menopausal symptoms: a short-term pilot study. Obstet Gynaecol Today 2002; 12: 727-730.

[109] Prakash J: Renalka Syrup in the Treatment of Urinary Tract Infection. Indian Journal of Clin Pract 2001; 12:63-66. 
[110] Bopana $\mathrm{N}$ and Saxena S: In vitro propagation of a high value medicinal plant: Asparagus racemosus Wild. In Vitro Cell Dev Biol-Plant 2008; 44:525-532.

[111] Kar D and Sen S: Effect of hormone on chromosome behaviour in callus cultures of Asparagus racemosus. Biol Plant 1985; 27:6-9. 